\title{
THE INCIDENCE OF PYLORIC STENOSIS IN DUNDEE
}

\author{
BY \\ DAVID LAWSON \\ From the Children's Department, Dundee Royal Infirmary
}

(Received for Publication April 3, 1951)

The mechanisms whereby pyloric stenosis develops are unknown. As a genetic factor is probably concerned in the aetiology, and as race differences in the frequency of the disease have been observed, it seems desirable that the incidence in a community should be recorded whenever the opportunity arises.

The city of Dundee is well situated for a study of the incidence of a disease which necessitates admission to hospital, as geographical considerations make it almost certain that any case arising within the city will be admitted to one of two hospitals.

This report refers to all cases of pyloric stenosis admitted during the seven years 1940 to 1946 . During this period there were 84 cases, of which 32 were in families living within the city boundaries: only these $\mathbf{3 2}$ are included in this series, thus enabling the incidence to be expressed as a proportion of the total live births in the city during the same period.

These figures necessarily refer to what Davison (1946) has called the 'manifest incidence' of the disease. There may well have been a few mild cases of the kind which Wallgren (1941) and others describe, in which recovery took place spontaneously

TABLE 1

Rates of Incidence of Pyloric Stenosis in Three Cities

\begin{tabular}{c|c|c|c|c}
\hline & $\begin{array}{c}\text { Live } \\
\text { Births }\end{array}$ & Cases & $\begin{array}{c}\text { Incidence per } \\
1,000 \text { Live } \\
\text { Births }\end{array}$ & $\begin{array}{c}\text { S.E. of } \\
\text { Sample }\end{array}$ \\
\hline $\begin{array}{c}\text { Dundee, } \\
1940-46 \ldots\end{array}$ & 21,288 & 32 & $1 \cdot 5$ & 0.26 \\
\hline $\begin{array}{c}\text { Newcastle, } \\
1939-42 \ldots\end{array}$ & 17,457 & 49 & $2 \cdot 8$ & 0.40 \\
\hline $\begin{array}{c}\text { Gothenburg, } \\
1934-40\end{array}$ & 25,642 & 102 & $4 \cdot 0$ & 0.39 \\
\hline
\end{tabular}

but in which radiological examination would have enabled a diagnosis to be made. Every case recorded here was severe enough to leave no clinical doubt about the diagnosis, which was in each case confirmed at operation.

It is fortunate that during this period no physician on the staff of either hospital was treating cases without operation. It is also known that no surgeon on the staff of either hospital treated any case in a private nursing home during this time, and that no post-mortem examination was performed in the city on a case undiagnosed during life.

Of 21,288 live babies born during these seven years, 32 developed pyloric stenosis, of whom 23 were boys and nine girls, giving an overall rate of 1.5 per 1,000 live births, or a rate in male births of $2 \cdot 1$ per 1,000 and in female births of 0.9 per 1,000 . These results are tabulated and are compared with the figures published by Davison for Newcastle and by Wallgren for Gothenburg. The rate observed in Dundee differs significantly from that observed in Gothenburg; this difference is great enough to suggest a real genetic difference between the two populations. The differences between Dundee and

TABLE 2

Significance of Differences Between ObSERVEd RATES

\begin{tabular}{|c|c|c|c|c|}
\hline & \multirow{2}{*}{$\begin{array}{c}\text { Difference/ } \\
\text { 1,000 Live } \\
\text { Births }\end{array}$} & \multirow{2}{*}{$\begin{array}{c}\text { S.E. of } \\
\text { Difference }\end{array}$} & \multicolumn{2}{|c|}{ Significance } \\
\hline & & & $P=0.05$ & $P=0.01$ \\
\hline $\begin{array}{l}\text { Dundee/ } \\
\text { Newcastle .. }\end{array}$ & $1 \cdot 3$ & $0 \cdot 5$ & + & - \\
\hline $\begin{array}{l}\text { Dundee/ } \\
\text { Gothenburg }\end{array}$ & $2 \cdot 5$ & 0.5 & + & + \\
\hline $\begin{array}{l}\text { Newcastle/ } \\
\text { Gothenburg }\end{array}$ & $1 \cdot 2$ & $0 \cdot 6$ & \pm & - \\
\hline
\end{tabular}


Newcastle and between Newcastle and Gothenburg are barely significant.

\section{Conclusions}

The observed incidence of pyloric stenosis, $1 \cdot 5$ cases of congenital hypertrophic pyloric stenosis per 1,000 live births, in a seven year study of Dundee probably indicates a true incidence of between 1 and 2 per 1,000 live births.
My thanks are due to the physicians and surgeons of Dundee Royal Infirmary and of Maryfield Hospital for their cooperation and for permission to publish my findings, and in particular to Dr. James Thomson in whose department the work was carried out.

REFERENCES

Davison, G. (1946). Archives of Disease in Childhood, 21, 113.

Wallgren, A. (1941). Amer. J. Dis. Child., 62, 751. 